\title{
УТРИМАННЯ АТОМІВ І МАЛИХ ЧАСТИНОК \\ ОПТИЧНОЮ ПАСТКОЮ, СФОРМОВАНОЮ \\ ПОСЛІДОВНОСТЯМИ ЗУСТРІЧНИХ \\ СВІТЛОВИХ ІМПУЛЬСІВ ВЕЛИКОЇ ПЛОЩ
}

\section{В.I. РОМАНЕНКО, Л.П. ЯЦЕНКО}

\author{
удк 535.214 Інститут фізики НАН України \\ (2012 (Просп. Науки, 46, Київ 03680)
}

\begin{abstract}
Запропоновано нову пастку для атомів і малих частинок, в основі якої - взаємодія атома 3 полем зустрічних імпульсів, що частково накладаються у часі. Суттєвою відмінністю від відомих аналогів є близька до адіабатичної взаємодія атома 3 полем, що дозволяє протягом того ж часу взаємодії передати атому значно більший імпульс і зменшити розмір пастки. Показано, що завдяки залежності світлового тиску від швидкості під час взаємодії з полем відбувається охолодження ансамблю атомів.
\end{abstract}

\section{1. Вступ}

Керування рухом атомів у світлових полях давно вже вийшло за межі пропозицій і стало звичайним засобом фізичних експериментів [1-4]. Водночас висловлюються пропозиції нових підходів у цій галузі. Наприклад, у роботах [5-7] показано, що зміна імпульсу атома при взаємодії із зустрічними імпульсами світла, що частково перекриваються у часі, може значно перевищити подвійний імпульс фотона - фундаментальну межу передачі імпульсу у випадку, коли атом взаємодіє із зустрічними імпульсами почергово $[9,10]$.

Як правило, атом, перебуваючи у оптичній пастці, неперервно взаємодіє з полем. Це може бути помітною перешкодою у фізичних експериментах, зокрема, у лазерній спектроскопії. Можливий вихід з цього становища - організувати взаємодію атома з полем так, щоб атом тільки невелику частину часу перебував під дією лазерного випромінювання, тобто побудувати світлові пастки на основі зустрічних світлових імпульсів [11-14]. Суттєво, що несучі частоти зустрі- чних імпульсів у цитованих роботах збігаються, і в результаті сила, що діє на атом, не перевищує $2 \hbar k / T$, де $T$ - період повторення імпульсів, $\hbar k$ - імпульс фотона.

Ми пропонуємо поєднати переваги малого збурення атома в імпульсній пастці з можливістю значного збільшення сили світлового тиску у пастці завдяки багатофотонній взаємодії, яка лежить в основі пропозицій збільшення переданого атому імпульсу значно вище $2 \hbar k[5-8]$. Для цього взаємодія атома з полем повинна бути адіабатичною, тобто площа світлових імпульсів має значно перевищувати $\pi$. Різниця між двома схемами взаємодії дворівневого атома з полем зустрічних імпульсів, що розглядаються у $[5,7,8]$ полягає в тому, що у роботах $[5,8]$ атом взаємодіє 3 полем зустрічних імпульсів 3 різними несучими частотами, а у роботі [7] миттєві несучі частоти лінійно змінюються з часом. У результаті напрямок переданого атому імпульсу за час взаємодії з полем різний. У першому випадку напрямок зміни імпульсу атома "протиінтуїтивний" - у напрямку поширення світлового імпульсу, котрий другим взаємодіє з атомом, а у другому він збігається з напрямком поширення імпульсу, який першим взаємодіє з атомом. Унаслідок цієї різниці, як показано у розділі 3 , у першому випадку світлові імпульси формують потенціальний бар'єр для атомів, а у другому - потенціальну яму. Для того, щоб визначити, чи можна цей бар'єр і яму використати для формування оптичної пастки, у розділі 4 проаналізовано залежність сили, що діє на атом у полі послідовності імпульсів, від швидкості атома і показано, що у потенціальній ямі сила діє назустріч 


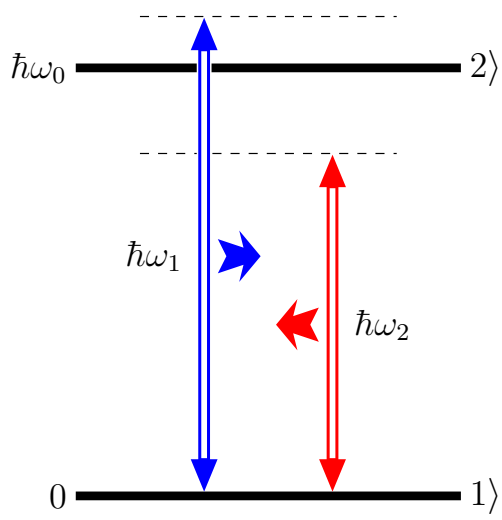

Рис. 1. Схема взаємодії атома зі світловими імпульсами з несучими частотами $\omega_{1}$ i $\omega_{2}$. Різниця енергій основного і збудженого станів дорівнює $\hbar \omega_{0}$

швидкості атома, що приводить до його гальмування у пастці. У випадку ж світлового бар'єра напрямок діючої на атом сили залежить від знака різниці частот першого і другого світлових імпульсів. У результаті можна побудувати пастку і в біхроматичному полі імпульсів, якщо бар'єри розташувати у просторі недалеко один від одного.

Запропонована оптична пастка може бути застосована і для утримання малих частинок, які містять атоми з вузькими спектральними лініями, що відповідають за перехід із основного у збуджений стан. Характеристики такої пастки оцінюються у розділі 5. Короткі висновки з роботи наведено у розділі 6.

\section{2. Основні рівняння}

Розглянемо дворівневий атом з основним станом $|1\rangle$, збудженим $|2\rangle$, і частотою переходу між ними $\omega_{0}$, що взаємодіє із полем

$\mathbf{E}(t)=E_{1}(t) \mathbf{e} \cos \left[\omega_{1} t-k_{1} z+\varphi_{1}(t)\right]+$

$+E_{2}(t) \mathbf{e} \cos \left[\omega_{2} t-k_{2} z+\varphi_{2}(t)\right]$

послідовностей зустрічних імпульсів (див. рис. 1). Тут $\omega_{1,2}-$ несучі частоти імпульсів, $\varphi_{1,2}(t)$ - в загальному випадку залежні від часу фази, $E_{1,2}(t)$ - обвідні імпульсів, е - орт поляризації електричного поля імпульсів. Для спрощення позначень у подальшому не будемо вказувати аргумент біля амплітуд полів і фаз, а також біля елементів матриці густини.

Взаємодію атома з полем описуємо у дипольному наближенні. Гамільтоніан такої взаємодії має вигляд

$H=\hbar \omega_{0}|2\rangle\left\langle 2\left|-\mathbf{d}_{12}\right| 1\right\rangle\left\langle 2\left|\mathbf{E}(t)-\mathbf{d}_{21}\right| 2\right\rangle\langle 1| \mathbf{E}(t)$, де $\mathbf{d}_{12}, \mathbf{d}_{21}$ - матричні елементи дипольного моменту d атома. Без порушення загальності [15] вважаємо, що $\mathbf{d}_{12} \mathbf{e}=\mathbf{d}_{21} \mathbf{e}$.

Рівняння для інверсії населеностей $w=\varrho_{22}-\varrho_{11}$ i когерентності $\varrho_{12}$, де $\varrho_{n m}$ - матриця густини атома, у наближенні обертової хвилі [15] має вигляд

$$
\begin{aligned}
& \dot{w}=2 \operatorname{Im} \varrho_{12}\left(\Omega_{1} e^{i k z-i \varphi_{1}-\frac{1}{2} i \delta t}+\right. \\
& \left.+\Omega_{2} e^{-i k z-i \varphi_{2}+\frac{1}{2} i \delta t}\right)-\gamma(1+w),
\end{aligned}
$$

$\dot{\varrho}_{12}=-\frac{i}{2}\left(\Omega_{1} e^{-i k z+i \varphi_{1}+\frac{1}{2} i \delta t}+\right.$

$\left.+\Omega_{2} e^{i k z+i \varphi_{2}-\frac{1}{2} i \delta t}\right) w+\left(i \Delta-\frac{1}{2} \gamma\right) \varrho_{12}$

де $\gamma$ - обернений час життя атома у збудженому стані, $\Omega_{1}=-d_{12} E_{1} / \hbar, \Omega_{2}=-d_{12} E_{2} / \hbar$,

$\delta=\omega_{1}-\omega_{2}, \quad \Delta=\omega_{0}-\frac{1}{2}\left(\omega_{1}+\omega_{2}\right)$.

Тут вибрано умову нормування у вигляді $\varrho_{11}+\varrho_{22}=1$ і покладено $k_{1}=k_{2}=k=\omega_{0} / c$.

Розглядаємо взаємодію атома $з$ полем послідовностей зустрічних імпульсів з періодом повторення $T$, одна 3 яких повторює іншу з певною затримкою в чаci $t_{d}$ у точці перебування атома:

$\Omega_{1,2}=\Omega_{0} f\left(\eta_{1,2}\right)$,

де функція $f_{\eta}$ з максимальним значенням $f(0)=1$ описує форму обвідної імпульсів:

$\eta_{1,2}=\left(2 t \mp t_{d}\right) / 2 \tau$,

де $t_{d}$ - різниця між часом приходу в точку, де перебуває атом, максимумів імпульсів, що поширюються у від'ємному і додатному напрямку осі $z, \tau$ - тривалість імпульсу.

Звичайно при моделюванні взаємодії атома 3 полем використовують імпульси гаусової форми $[17,18]$. Як відомо з $[8,19]$, функція $\cos ^{n}(\pi t / \tau)$ зі зростанням парного $n$ прямує до $\exp \left(-t^{2} / \tau_{G}^{2}\right)$ з $\tau_{g}=\tau \sqrt{2} / \pi \sqrt{n}$ на проміжку $|t|<\tau / 2$. Ми для чисельного моделювання виберемо $f(\eta)$ у вигляді

$f(\eta)= \begin{cases}\cos ^{4}(\pi \eta), & |\eta|<1 / 2 \\ 0, & |\eta|>1 / 2\end{cases}$ 


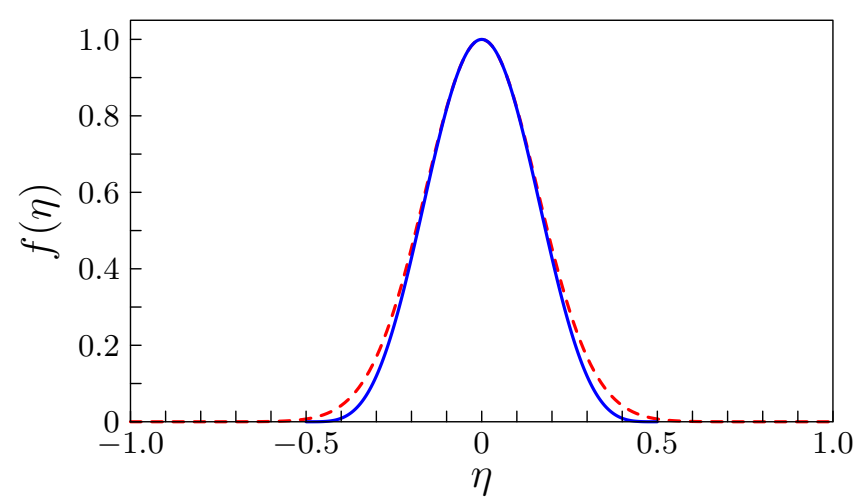

Рис. 2. Порівняння функції $f(x)$ (суцільна крива), що описує обвідну світлових імпульсів, 3 найближчою до неї гаусовою функцією (пунктир)

В околі кожного імпульсу ця функція близька до гаусової

$$
f_{G}(\eta)=\exp \left(-2 \pi^{2} \eta^{2}\right)
$$

на проміжку, де її значення немале (див. рис. 2). Порівняно з гаусовою функцією (8) вибрана нами для моделювання імпульсів функція (7), з одного боку, зручніша для чисельних розрахунків (гаусову функцію доводиться штучно обрізати у певних межах), а з іншого - відповідає реальним обвідним імпульсів, які обмежені у часі.

Площа імпульсу, обвідна якого описується функцією (7), дорівнює $\frac{3}{8} \Omega_{0} \tau$ і становить приблизно 0,94 площі близького до неї гаусового імпульсу.

Фази імпульсів $\varphi_{1,2}$ залежать від часу квадратично

$$
\varphi_{1,2}=\frac{\beta}{2} \eta_{1,2}^{2}
$$

так що миттева частота кожного з них

$$
\varpi_{1,2}=\omega_{1,2}+\dot{\varphi}_{1,2}=\frac{\beta}{\tau^{2}}\left(t \mp \frac{1}{2} t_{d}\right)
$$

лінійно змінюється з часом.

Вираз для сили світлового тиску на атом [16]:

$\mathcal{F}=2 \frac{\partial \mathbf{E}}{\partial z} \operatorname{Re} \varrho_{12} \mathbf{d}_{21} \exp \left(i\left(\omega_{0}-\Delta\right) t\right)$,

після усереднення на періоді осциляцій з частотою $\omega_{0}$ для поля (1) набуває вигляду

$$
\begin{aligned}
& \overline{\mathcal{F}}=\hbar k \operatorname{Im} \varrho_{12}\left(\Omega_{1} e^{i k z-\frac{1}{2} i \delta t-i \varphi_{1}(t)}-\right. \\
& \left.-\Omega_{2} e^{-i k z+\frac{1}{2} i \delta t-i \varphi_{2}(t)}\right) .
\end{aligned}
$$

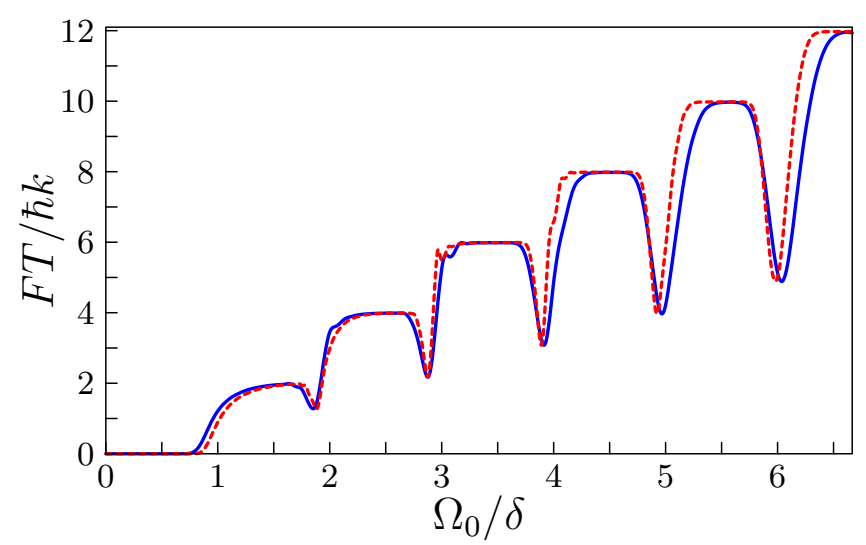

Рис. 3. Залежність сили світлового тиску, що діє на атом у полі зустрічних імпульсів, від частоти Рабі $\Omega_{0}$ в одиницях $\delta$, знайдена з числового розв'язку рівнянь (3) разом з (12), (13). Параметри: $T=100 \tau, \beta=0, \Delta=0, t_{d}=0,25 \tau, \gamma T=0,5$, $\delta \tau=300$ (суцільна крива) і 600 (пунктир). Усереднення сили проводилися після закінчення перехідних процесів $(t>10 T)$

Під час руху зі швидкістю $v$ вздовж осі $z$ координата атома змінюється і разом з нею змінюється сила, що діє на атом. Оскільки на довжині хвилі швидкість атома практично стала, то для розрахунку зміни імпульсу атома з часом використовуємо, як це раніше робилося при розрахунку світлового тиску на атоми у біхроматичному полі, усереднену на довжині хвилі $\lambda=2 \pi c / \omega_{0}$ силу світлового тиску:

$F=\frac{1}{\lambda} \int_{z}^{z+\lambda} \overline{\mathcal{F}}\left(z^{\prime}\right) d z^{\prime}$.

\section{3. "Важкий” атом. Сила світлового тиску i потенціальна енергія}

Якщо атом рухається вздовж осі $z$ зі швидкістю $v$, то відстроювання $\delta$ несучих частот світлових імпульсів 3 часом у системі відліку атома змінюється за законом:

$\delta=\delta_{0}-2 k \int_{0}^{t} v\left(t^{\prime}\right) d t^{\prime}$,

де $\delta_{0}-$ початкове відстроювання.

Розглянемо спочатку силу світлового тиску на атом у наближенні "важкого" атома, коли зміна відстроювання несучих частот світлових імпульсів від частоти переходу $\omega_{0}$ протягом руху атома у полі мало впливає на величину сили світлового тиску, що діє на атом. Це так, наприклад, коли другий доданок у (14) малий порівняно з першим. Якщо ж ми розглядаємо імпульси 

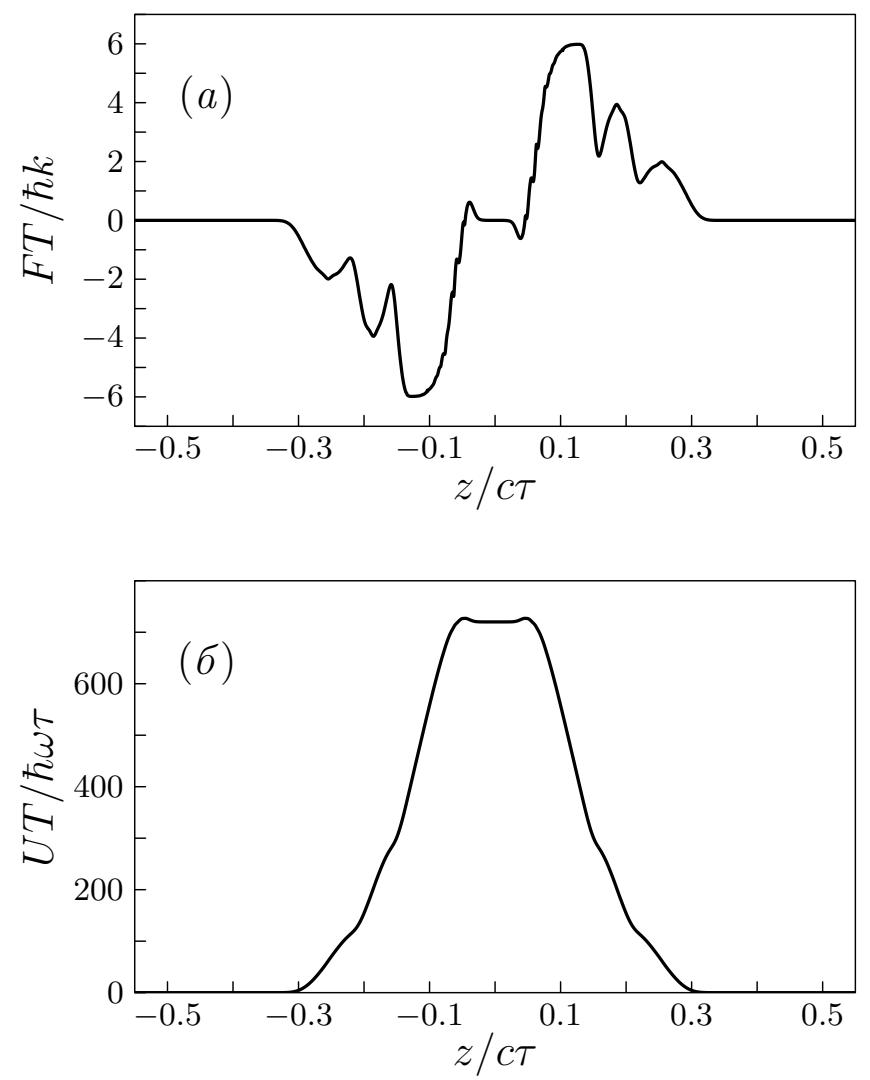

Рис. 4. Залежність сили світлового тиску, що діє на атом у полі зустрічних імпульсів $(a)$, і його потенціальної енергї від координати, знайдена з числового розв'язку рівнянь (3) разом з (12), (13) (б). Параметри: $T=100 \tau, \beta=0, \Delta=0, \gamma T=0,5$, $\delta \tau=300, \Omega_{0} \tau=1000$. Усереднення сили проводилися після закінчення перехідних процесів $(t>10 T)$

зі змінними у часі миттєвими частотами $\varpi_{1,2}$, роль $\delta_{0}$ відіграє $\varpi_{1}-\varpi_{2}$, і ця величина повинна значно перевищувати $k v$ протягом переважної частини часу взаємодії атома з полем.

На рис. 3 показано приклад залежності діючої на атом сили світлового тиску у випадку нечирпованих світлових імпульсів $(\beta=0)$ від частоти Рабі світлових імпульсів. На відміну від робіт $[5,8]$ тут обчислено не середній переданий імпульс, а силу, що діє на атом протягом тривалого, $t \gg 1 / \gamma$, часу взаємодії атома 3 полем. Крім того, при обчисленні діючої на атом сили ми використовуємо рівняння для матриці густини, які дозволяють, на відміну від рівняння Шредінгера, проаналізувати замкнену схему взаємодії атома 3 полем, коли у результаті спонтанного випромінювання зі збудженого стану $|2\rangle$ він переходить у основний стан $|1\rangle$.
Як видно з рис. 3, залежність сили світлового тиску на атом від частоти Рабі у біхроматичному полі зустрічних світлових імпульсів приблизно сходинкоподібна, причому сходинки чіткіше видні на залежності, яка відповідає більшій площі світлових імпульсів (див. пунктирну криву). Висота кожної сходинки в одиницях $\hbar k / T$ близька до парного числа. Зазначимо, що сила $2 \hbar k / T$ - це максимальна величина сили світлового тиску на атом, яка може бути досягнута у полі світлових імпульсів, які почергово взаємодіють 3 атомом. Дійсно, при поглинанні фотона з одного світлового імпульсу імпульс атома може змінитися на імпульс фотона $\hbar k$, при взаємодії із зустрічним світловим імпульсом імпульс атома може змінитися ще на $\hbar k$ у тому ж напрямку.

В основі залежності, показаної на рис. 3, лежить адіабатичність взаємодії атома з біхроматичним полем $[5,8]$. У такому полі атом характеризується спектром квазіенергій [22] з періодом $\hbar \delta$, якому відповідає зміна імпульсу на $2 \hbar k$. Протягом адіабатичної взаємодії атома з полем він перебуває в одному з власних станів, з можливими переходами Ландау-Зінера в інші, з близькими значеннями квазіенергій, стани. У результаті імпульс атома протягом взаємодії з парою імпульсів змінюється на величину, кратну $2 \hbar k$. Коефіцієнт кратності близький до $\Omega_{0} / \delta$ (детальніше див. $[5,8])$.

Під час руху атома вздовж осі $z$ затримка $t_{d}$ між імпульсами в пов'язаній з ним системі відліку змінюється. Так, якщо атом перебуває у точці, в яку світлові імпульси приходять одночасно (ми виберемо їі за початок координат), $t_{d}=0$. Як бачимо, для атома 3 координатою $z$ затримка $t_{d}$ у часі між приходом у цю точку імпульсів, що поширюються у додатному і від'ємному напрямку осі $z$, дорівнює $2 z / c$.

На рис. 4, а наведено приклад залежності сили, котра діє на атом, від його координати у випадку поля зі сталими миттєвими частотами $(\beta=0)$. Як видно, сила світлового тиску в області, де світлові імпульси почергово взаємодіють з атомом, дорівнює нулю. Це пов'язано з тим, що, завдяки великій площі імпульсів і великому відстроюванню несучих частот світлових імпульсів від резонансу $\left|\omega_{1}-\omega_{0}\right|=\left|\omega_{2}-\omega_{0}\right|=$ $\delta / 2 \gg 1 / \tau$, атом весь час перебуває в одному з адіабатичних станів. У результаті відбувається когерентне повернення населеностей [23] - стан атома у кінці взаємодії з полем збігається зі станом на початку, тому імпульс атома при взаємодії з одним світловим імпульсом не змінюеться і сила світлового тиску дорівнює нулю. 
На рис. 4,б показано залежність потенціальної енергії $U$ атома, що визначається рівнянням

$F=-\frac{d U}{d z}$

від його координати. Початок відліку потенціальної енергї вибрано так, щоб за межами перекриття імпульсів вона дорівнювала нулю. Як видно, зустрічні світлові імпульси формують потенціальний бар'єр для атомів.

На рис. 5, а наведено приклад залежності сили, котра діє на атом, від його координати у випадку поля $з$ лінійно змінними у часі миттєвими частотами $(\beta=200)$. На відміну від рис. $4, a$, сила світлового тиску в області, де світлові імпульси почергово взаємодіють з атомом, відмінна від нуля і близька до $2 \hbar k / T$. Це пов'язано з адіабатично швидким проходженням резонансу [15] при взаємодії одного зі світлових імпульсів з атомом, у результаті чого атом переходить з основного стану у збуджений з поглинанням фотона і зміною імпульсу на $\hbar k$. При взаємодії із зустрічним імпульсом наявне вимушене випромінювання фотона зі зміною імпульсу ще на $\hbar k$ у тому самому напрямкy [10].

На рис. 4,б показано залежність потенціальної енергї атома для поля з лінійно змінними у часі миттєвими частотами. На відміну від взаємодії атома $з$ полем зустрічних імпульсів із миттєвими частотами, у цьому випадку формується потенціальна яма для атома.

Таким чином, поле зустрічних імпульсів з фіксованими чи лінійно змінними у часі частотами дозволяє створювати у просторі потенціальні бар'єри чи потенціальні ями, що може бути використано для управління рухом чи для локалізації у певній області простору атомів або наночастинок, які містять у собі атоми з вузькою лінією поглинання. Наприклад, потенціальну яму можна безпосередньо використовувати для утримання атомів у малій області простору, а два потенціальні бар'єри, які нескладно зробити з двох пар зустрічних послідовностей імпульсів, можна використати для формування оптичної пастки між ними.

Під час створення пасток важливим питанням є залежність сили світлового тиску від швидкості, яка може привести як до зростання енергії атома 3 можливим виходом за межі пастки, так і до її зменшення, що відповідає стійкій локалізації атома у пастці.
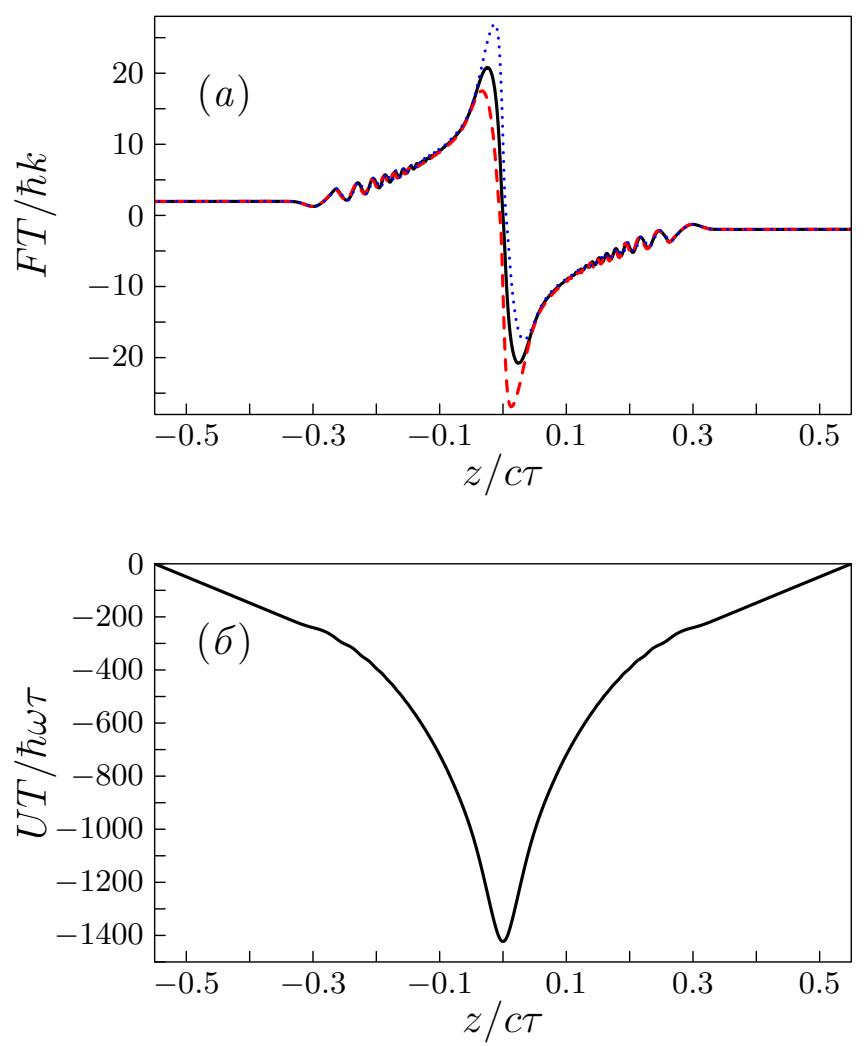

Рис. 5. Залежність сили світлового тиску, що діє на атом у полі зустрічних імпульсів $(a)$, і потенціальної енергії від його координати, знайдена з числового розв'язку рівнянь (3) разом з (12), (13) (б). Параметри: $T=100 \tau, \beta=200, \Delta=0, \gamma T=0,5$, $\Omega_{0} \tau=500$. Суцільна лінія $-\delta=0$, пунктир $-\delta \tau=-2$, крапки $-\delta \tau=2$. Усереднення сили проводилися після закінчення перехідних процесів $(t>10 T)$

\section{4. Оптична пастка, сформована послідовностями зустрічних імпульсів}

У процесі тривалої взаємодії атома з полем швидкість атома змінюється, і разом з нею, згідно із (14), у системі відліку атома змінюється різниця несучих частот світлових імпульсів, що на нього діють. Розглянемо спочатку світлові імпульси з фіксованою несучою частотою $(\beta=0)$. Нехай $\delta_{0}>0$ і $v>0$. Тоді зі зростанням $v$ зменшується $\delta$ і зростає $\Omega_{0} / \delta$. У той самий час з рис. 2 видно, що у цілому зі зростанням $\Omega_{0} / \delta$ сила світлового тиску, що діє на атом, зростає. Таким чином, зростання $v>0$ приводить до зростання діючої на атом сили. Якщо ж $v<0$ і $|v|$ зростає, аналогічні міркування приводять до висновку, що сила світлового тиску зменшується.

Нехай атом рухається уздовж осі z у бік бар'єpa, створеного послідовностями зустрічних імпульсів, 


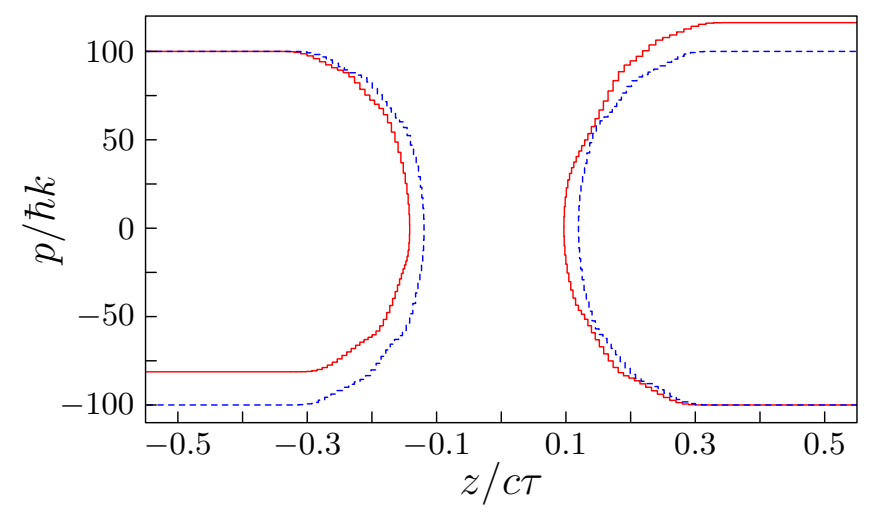

Рис. 6. Фазова траєкторія атома у полі послідовностей зустрічних імпульсів. Параметри: $T=100 \tau, \beta=0, \Delta=0, \gamma T=0,5$, $\delta \tau=300, \Omega_{0} \tau=1000, \alpha=10^{-6}$. Усереднення сили проводилося після закінчення перехідних процесів $(t>10 T)$. Початкове значення імпульсу $p_{\text {ini }}=100 \hbar k$ для лівої частини рисунка $\mathrm{i}$ $p_{\text {ini }}=-100 \hbar k$ для правої частини рисунка. Суцільна крива $\mu=1$, пунктир $-\mu=0$

причому спочатку на нього діє імпульс з більшою несучою частотою (тобто $\delta>0$ ). При досягненні бар'єра його гальмує сила світлового тиску, і швидкість атома зменшується. Після відбиття від бар'єра швидкість зростає, оскільки вона спрямована у протилежний бік, згідно з наведеними вище міркуваннями сила світлового тиску менша, ніж при русі у бік бар'єра. Таким чином, атом після відбиття від бар'єра, який знаходиться від нього у додатному напрямку осі $z$, при $\delta>0$ відлітає від нього з меншою за початкову швидкість. Якщо ж атом налітає на бар'$\epsilon \mathrm{p}$, рухаючись у від'ємному напрямку осі $z$, то згідно з аналогічними міркуваннями його швидкість після відбиття від бар'єра перевищує початкову. На рис. 6 показано фазову траєкторію атома для обох випадків руху - з початковою швидкістю, направленою у додатному (права частина рисунка) і від'ємному (ліва частина рисунка) напрямку осі $z$, яка відображає (суцільна крива) збільшення чи зменшення швидкості атома при відбитті від бар'єра залежно від напрямку його початкової швидкості. Пунктиром показано, якою мала б бути фазова траєкторія у наближенні дуже важкого атома, коли $k v \lll \delta_{0}$.

При розрахунку зміни імпульсу атома ми знехтували впливом зміни швидкості на силу світлового тиску під час взаємодії атома з полем пари імпульсів і обчислювали зміну імпульсу атома так: спочатку розраховували зміну імпульсу атома:

$\Delta p=\int_{t_{\mathrm{ini}}}^{t_{\mathrm{fin}}} F d t$,

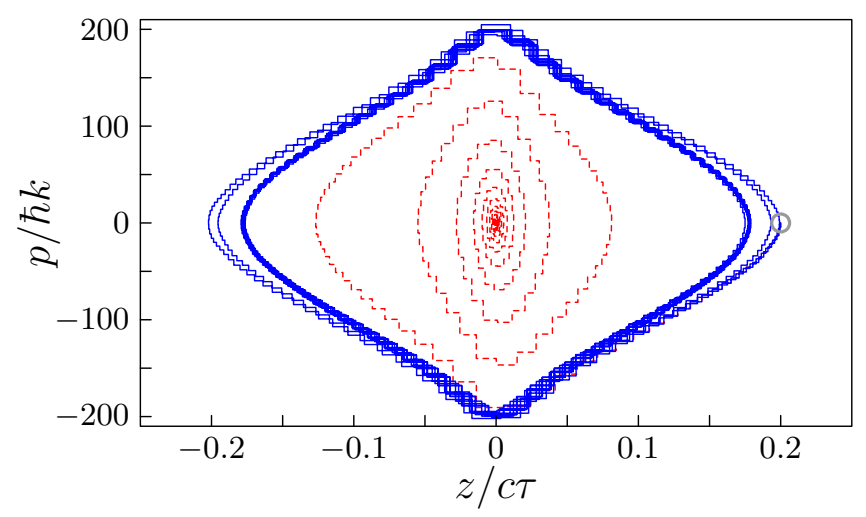

Рис. 7. Фазова траєкторія атома у полі послідовностей зустрічних імпульсів. Параметри: $T=100 \tau, \beta=200, \Delta=0$, $\gamma T=0,5, \delta=0, \Omega_{0} \tau=500, \alpha=10^{-6}$. Усереднення сили проводилося після закінчення перехідних процесів $(t>10 T)$. Початкове значення координати $z_{\text {ini }}=0,2 c \tau$ (показано справа сірим кільцем). Суцільна крива $-\mu=0$, пунктир $-\mu=0,01$

де $t_{\text {ini }}$ i $t_{\text {fin }}$ - початок i закінчення взаємодії атома з полем пари імпульсів, потім обчислювали зміну швидкості атома:

$\Delta v=\frac{\Delta p}{M}$

де $M$ - маса атома. I вже з цією швидкістю і відповідним їй значенням $\delta$, обчисленого із $(14)$, повторювали процес розрахунку з наступною парою імпульсів. Для ілюстративного розрахунку вибрано завищене значення параметрів $\mu=\hbar k^{2} \tau / M$ і $\alpha=\hbar k / c M$, які відповідають за залежність безрозмірного відстроювання $\delta \tau$ від імпульсу атома в одиницях $\hbar k$ :

$\delta \tau=\delta_{0} \tau-\mu \cdot\left(\frac{p}{\hbar k}\right)$

і зміну безрозмірної координати $\Delta z / c \tau$ зі зміною безрозмірного часу $\Delta t / \tau$ :

$\frac{\Delta z}{c \tau}=\alpha\left(\frac{p}{\hbar k}\right) \frac{\Delta t}{\tau}$.

Вибираючи різницю частот світлових імпульсів таким чином, щоб швидкість атома після взаємодії зі сформованим цими імпульсами бар'єром зменшувалася і розташовуючи два бар'єри поруч, можна отримати одновимірну пастку для атомів.

Дослідимо тепер можливість створення пастки на основі зустрічних імпульсів зі змінною миттєвою частотою. На рис. 5, а побудовано залежності сили від координати атома при різних за знаком, але однакових за величиною значеннях $\delta$. Додатний знак $\delta$ при 
$\delta_{0}=0$ відповідає згідно із (14) рухові атома у від'ємному напрямку осі $z$, від'ємний - у додатному. Неважко бачити, що сила світлового тиску при русі атома від початку координат менша, ніж при русі у зворотному напрямку. Таким чином, слід чекати стабільного утримання атома полем зустрічних імпульсів зі змінними частотами.

На рис. 7 проілюстровано рух атома у пастці, створеній зустрічними послідовностями світлових імпульсів зі змінними у часі частотами. Як видно, з часом, завдяки доплерівському зсуву несучих частот світлових імпульсів у системі відліку атома, він локалізується у центрі пастки. Слід зазначити, що це не означає, що всі атоми зберуться у центрі - розглянута модель класичного руху атома у світловому полі не враховує імпульсної дифузії [16]. Для оцінки області локалізації, що становитиме предмет подальших досліджень, слід застосувати квантово-механічний опис руху атома.

На відміну від світлової пастки, сформованої послідовностями зустрічних $\pi$-імпульсів чи імпульсів малої площі [11-14], сила світлового тиску в області просторового перекриття імпульсів не зменшується, а зростає. У результаті потенціальна яма у цій області стає значно глибшою.

Залежно від способу реалізації пастки, з імпульсами з фіксованою частотою чи зі змінною у часі миттєвою частотою, інтенсивність імпульсів може значно відрізнятися. У роботі [7] порівняно інтенсивності, необхідні для передачі атома одного і того ж імпульсу для змінною з часом і фіксованою миттєвою частотою для наносекундних імпульсів, що діють на атоми гелію і рубідію. Згідно з наведеними у цій роботі оцінками, для імпульсів з фіксованою частотою необхідна інтенсивність становить близько $1 \mathrm{MB} / \mathrm{cm}^{2}$, а для імпульсів зі змінною у часі частотою - кілька $\mathrm{kB} \mathrm{T} / \mathrm{cm}^{2}$.

\section{5. Пастки для наночастинок}

Запропонована оптична пастка для атомів може бути використана для захоплення і утримання наночастинок. Для цього частинки повинні містити "активні" атоми з вузькими лініями поглинання в достатній концентрації. Оцінимо мінімальну концентрацію "активних" атомів у наночастинці. Очевидною вимогою для можливості утримання наночастинки і маніпуляції нею є значне переважання сили світлового тиску $F$ над силою тяжіння $M g$. Оцінимо силу світлового тиску на атом. Вона, у межах просторового перекриття імпульсів, становить величину поряд- ку $10 \hbar k / T$. Для довжини хвилі $\lambda \sim 600$ нм частоти повторення імпульсів $T^{-1} \sim 100$ Мгц і атома з масою $\sim 50$ а.о.м. $F / m g \sim 10^{6}$. Таким чином, вже при концентрації "активних" атомів у наночастинках понад 0,001\% можливе їх утримання у оптичних пастках, сформованих зустрічними світловими імпульсами великої площі.

\section{6. Висновки}

Запропоновані оптичні пастки, в основі яких лежить адіабатична взаємодія атомів, у тому числі атомів у наночастинках, з послідовностями зустрічних імпульсів великої площі, порівняно з пастками на основі $\pi$ імпульсів та імпульсів малої площі, характерні збільшенням сили світлового тиску у просторовій області перекриття імпульсів, що дозволяє локалізувати атоми і наночастинки у меншому об'ємі. Крім того, завдяки залежності сили світлового тиску в цих пастках від швидкості атома енергія атомів у пастці зменшується. Питання щодо максимального охолодження атомів у пасках залишається відкритим - для його дослідження недостатньо класичного опису руху атома у пастці, використаного у роботі.

Робота виконана за темами ДЦНТП "Нанотехнології та наноматеріали (2010-2014)" 1.1.4.13, 3.5.1.24.

1. S. Chu, Rev. Mod. Phys. 70, 685 (1998).

2. C.N. Cohen-Tannoudji, Rev. Mod. Phys. 70, 707 (1998).

3. W.D. Phillips, Rev. Mod. Phys. 70, 721 (1998).

4. V.I. Balykin, V.G. Minogin, V.S. Letokhov, Rep. Prog. Phys. 63, 1429 (2000).

5. В.И. Романенко, Л.П. Яценко, ЖЭТФ 117, 467 (2000); [V.I. Romanenko, L.P. Yatsenko, JETP 90, 407 (2000)].

6. В.И. Романенко, Л.П. Яценко, ЖЭТФ 127, 273 (2005); [V.I. Romanenko, L.P. Yatsenko, JETP 100, 242 (2005)].

7. G. Demeter, G.P. Djotyan, Zs. Sörlei, and J. S. Bakos, Phys. Rev. A 74, 013401 (2006).

8. А.М. Негрійко, В.І. Романенко, Л.П. Яценко, Динаміка атомів $і$ молекул в когерентних лазерних полях, (Наукова Думка, Київ, 2008).

9. А.П. Казанцев, ЖЭТФ 66, 1599 (1974); [А.Р. Каzantsev, Sov. Phys. JETP 39784 (1974)].

10. I. Nebenzahl and A. Szöke, Appl. Phys. Lett. 25, 327 (1974). 
11. T.G.M. Freegarde, J. Waltz, and T.W. Hänsch, Opt. Commun. 117, 262 (1995).

12. A. Goepfert, I. Bloch, D. Haubrich, F. Lison, R. Schütze, R. Wynands, and D. Meshede, Phys. Rev. A 56, R3345 (1997).

13. V.I. Balykin, JETP Lett. 81, 206 (2005).

14. V.I. Romanenko, L.P. Yatsenko, J. Phys. B: At. Mol. Opt. Phys. 44, 115305 (2011).

15. B.W. Shore, The Theory of Coherent Atomic Excitation, Vol. 1, (Wiley, New York, 1990).

16. В.Г. Миногин, В.С. Летохов, Давление лазерного излучения на атомы (Наука, Москва, 1986).

17. K. Bergmann, H. Theur, and B.W. Shore Rev. Mod. Phys. 70, 1003 (1998).

18. N.V. Vitanov, T. Halfmann, B.W. Shore, K. Bergmann, Ann. Rev. Phys. Chem. 52, 763 (2001).

19. В.I. Романенко, УФЖ 51, 1054 (2006); [V.I. Romanenko, Ukr. J. Phys. 51, 1054 (2006)].

20. В. С. Войцехович, М.В. Данилейко, А.М. Негрийко, В.И. Романенко, Л.П. Яценко, ЖТФ 58, 1174 (1988); [V.S. Voitsekhovich, M.V. Danileiko, A.M. Negriyko, V.I. Romanenko, L.P. Yatsenko, Sov. Phys. Tech. Phys. 33, 690 (1988)].

21. В. С. Войцехович, М.В. Данилейко, А.М. Негрийко, В.И. Романенко, Л.П. Яценко, ЖЭТФ 99, 393 (1991); [V. S. Votsekhovich, M. V. Danileko, A.M. Negriyko, V.I. Romanenko, L.P. Yatsenko, Sov. Phys. JETP 72, 219 (1991)].

22. Я.Б. Зельдович, ЖЭТФ 51, 1492 (1966).

23. N.V. Vitanov, B.W. Shore, L. Yatsenko, K. Böhmer, T. Halfmann, T. Rickes, and K. Bergmann, Opt. Commun. 199, 117 (2001).

Одержано 14.11.11
УДЕРЖАНИЕ АТОМОВ И МАЛЫХ ЧАСТИЦ ОПТИЧЕСКОЙ ЛОВУШКОЙ, СФОРМИРОВАННОЙ ПОСЛЕДОВАТЕЛЬНОСТЯМИ ВСТРЕЧНЫХ ИМПУЛЬСОВ БОЛЬШОЙ ПЛОЩАДИ

В.И. Романенко, Л.П. Яценко

Р е з ю м е

Предложена новая ловушка для атомов и малых частиц на основе взаимодействия атомов с полем встречных импульсов, частично перекрывающихся во времени. Существенное отличие от известных аналогов заключается в близком к адиабатическому взаимодействие с полем, что позволяет в течение того же времени передать атому значительно больший импульс и уменьшить размер ловушки. Показано, что благодаря зависимости светового давления от скорости происходит охлаждение атомов.

CAPTURE OF ATOMS AND SMALL PARTICLES

IN AN OPTICAL TRAP FORMED BY SEQUENCES

OF COUNTER-PROPAGATING LIGHT PULSES WITH A LARGE AREA

V.I. Romanenko, L.P. Yatsenko

Institute of Physics, Nat. Acad. of Sci. of Ukraine (46, Nauky Ave., Kyiv 03028,Ukraine; e-mail:vr@iop.kiev.ua)

$\mathrm{S} \mathrm{u} \mathrm{m} \mathrm{m} \mathrm{a} \mathrm{r} \mathrm{y}$

A new trap for atoms and small particles based on the interaction between an atom and a field of counter-propagating light pulses that are partially superposed in time has been proposed. A substantial difference from known analogs consists in that the atom-field interaction is close to adiabatic one, which allows a considerably higher momentum to be transferred to the atom within the same time interval and makes the trap smaller in size. It has been shown that, owing to the dependence of light pressure force on the atom velocity, the atomic ensemble is cooled down at its interaction with the field. 